\title{
SEASONAL FOOD AND FEEDING HABITS OF NAZIRITOR CHELYNOIDES (MC CLELLAND) 1839 OF MARDI KHOLA, KASKI, NEPAL
}

\author{
O. H. Shrestha and J. Shrestha
}

\begin{abstract}
The fishes (Naziritor chelynoides) were collected in different months with the help of local devices (cast net and tiyari). The collected specimens were dissected in the laboratory and their gut contents were analyzed dividing food items (dietary items) into different groups viz., algae, diatoms, insects and fragments etc. The gut of fish consisted of different dietary items (plant origin and animal origin) indicating Naziritor chelynoides as an omnivorous fish. The average percentage of algae was found as 27.89 and average percentage of insects, diatoms and fragments were found as 20.15, 19.26 and 3.61 respectively. Water quality analysis of the Mardi khola (study area) revealed that the transparency of the water was crystal clear except in the rainy season. The dissolved oxygen was found in an optimum level $(12.65 \mathrm{mg} /$ I). The average temperature of the river was found as $19.120 \mathrm{C}$ and the average $\mathrm{pH}$ was found as 8.41 during the study period.
\end{abstract}

Key words: Feeding habits, Mardi Khola, omnivorous, water quality analysis

\section{Introduction}

This country Nepal is blessed with water resources as well as fishery resources. She is rich in fish diversity. From the taxonomic revision, there are 184 fish species (Shrestha, 2003) belonging to 93 genera, 31 families and 11 orders existing in natural water bodies of Nepal while, Rajbansi (2005) has listed 186 species from Nepal. Recently $\mathrm{Ng}$ and Edds (2004, $2005 \mathrm{a} \mathrm{b}$ ), Edds and $\mathrm{Ng}$ (2004) and $\mathrm{Ng}$ (2006) have listed 6 new species and 11 new records from Nepal which further increased the total number of fish species of Nepal. Consequently 184 fish species of Nepal has increased to a total of 199 species till now. Among them one of the cold water fish, Naziritor chelynoides, formerly called as Puntius chilinoides (Jayram, 1981, 99), is a cold water cyprinid. It is an omnivorous fish which breeds in March to June. The fish is as tasty as Katle (Neolissocheilus hexagonolepis) but smaller than it (Rai, 1989). The fish is distributed in the Kulekhani Reservoir, Phewa lake, Mardi Khola and Trishuli river. The altitudinal range is from $784 \mathrm{~m}$ to $1430 \mathrm{~m}$ (Shrestha, 1994).

The present study area was Mardi Khola which is one of the most important feeder stream of Seti Khola that flows from the northern corner of Pokhara valley of Kaski district, a snow- fed river originating from Mardi Himal, 5,587m (John, 1986).

The natural food of fishes may be classified into different groups viz. Plankton, Nekton, Benthos and Detritus. Different fish species living together in a confined water body may not have the same feeding habits. Various anatomical features confine their feeding types which can be categorized as either herbivorous or carnivorous or omnivorous. Seasonal variations also affect the 
intake of food items in fishes. The study related to feeding behavior of Nepalese fish species is very scanty. Authors like Shrestha (1974), Upadhyaya (1976), Shrestha (1989), Karki (1978) and Shrestha (1993) have studied on feeding behavior of the fishes of Pseudecheneis sulcatus, Schizothorax plagiostomus, Schozothoraichthys annandalei, Channa gachua, Heteropneustes fossilis and Garra anandalei and Schizothorax plagiostomus respectively. However, the gap of study in the same topic is frequently observed. The study is carried out to fulfill the gap of study to some extent and also to promote the growth of fishes (Naziritor chelynoides) by the study of feeding pattern, useful for culture practice. However, for this purpose the biological study of the fishes should be carried out intensely. During the study period, among the four sampling sites, only from the III and IV sites, phytoplanktons were recorded while first two sites lack them. Similarly Naziritor chelynoides were also absent in I and II sites and present only in III and IV sites. The exact reason behind this is unknown, however, high altitude, low water temperature, torrential water making unfavorable conditions to survive may be surmised for their absence in I and II sites.

\section{Study Area}

The present study area is the Mardi Khola, which is located at the northern corner of Pokhara valley of Kaski district. It is a snow - fed never orignating from Marti Himal, 5587m (John,1986) and terminates at Seti dovan joining with Seti khola. The total length of river from Sidding( first site) to Seti dovan (last site) is about $25 \mathrm{~km}$.

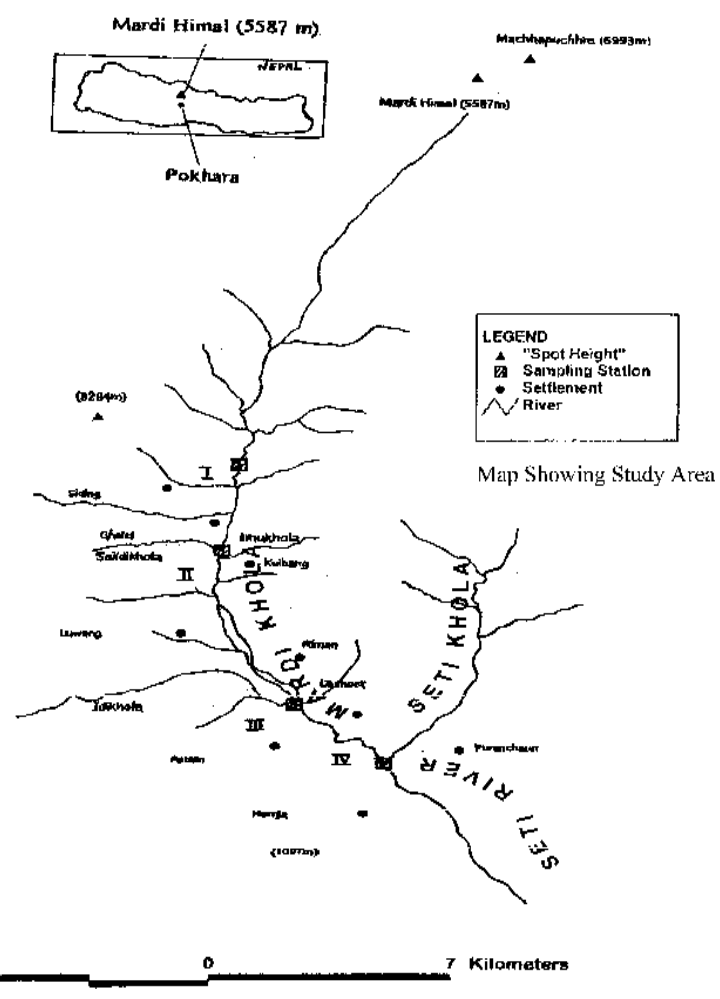

\section{Materials and Methods Study Period}

The field study was carried out for 10 months from July 2003 to April 2004. Samplings were done in the month of July, October, January and April covering the different seasons i.e. summer, autumn, winter and spring of the year.

\section{Sampling sites}

Four different sampling sites were selected in whole stretch of river by direct observation on the basis of physiographical condition as well as human impact areas. The sampling sites were designated as sampling sites I (above Siding village), II (at Saitighatta), III (at Ididovan) and IV (at Seti dovan) respectively. 
well as human impact areas. The sampling sites were designated as sampling sites I (above Siding village), II (at Saitighatta), III (at Ididovan) and IV (at Seti Dovan) respectively.

\section{Fish sampling}

The fishes were collected from each site. Locally available devices i.e. cast net and tiyari were used for the collection purpose with the help of local fishermen. After netting Naziritor chelynoides were separated and their measurements were taken and then preserved in $10 \%$ formalin for lab work. Specimens were identified according to the keys of Shrestha (1981, 2003) and Jayram (1999).

\section{Gut content analysis}

Alimentary canals were removed and their contents were identified with the aid of stereoscope microscope. The food items (dietary items) were identified to the lowest taxonomic units using the keys of Nedham and Nedham (1962), Pennak (1978), and APHA (1995).

\section{Water quality analysis}

Water quality analysis is one of the most important aspects in the study of aquatic environment. Among physical, chemical and biological parameters, biological parameters were more emphasized; however, some of the phisico- chemical parameters were also analyzed.

\section{Result and Discussion}

Fishes differ greatly in the characters of food they consume. Same species living in different ecological niche perhaps may not have same food items in their gut. Foods of fishes in earlier states differ from that of adult stages and sometimes the foods of different sexes also differ. Generally fishes are herbivorous, carnivorous or omnivorous in their feeding habits. Most of them are highly adaptable in their feeding habits and utilize the readily available food. The gut content of fishes can not be explained by single factor rather it is dependent on different factors viz. availability of food items, structural modifications (like gill rakers) of fish, seasonal variation and so on (Khanna, 1996).

Naziritor chelynoides is one of the most important hill stream fish of Mardi khola. It is an omnivorous that is counted as as tasty as Katle (Neolissocheilus hexagonolepis). It has thick lips with horny covering which help feed on algae. The mouth is transverse cleft which is situated towards the ventral side, behind the lip of the snout. Gill rakers were short and stumpy, a typical case of omnivorous type (John, 1986).

\section{Food Items}

The algae, which comprised of green algae, blue green algae were found to have reached the peak position (percentage) i.e. (31.40) in the month of January and the lowest (24.83) was recorded in the month of July. Due to flooding in the month of July, the algal bloom was covered by the silts. So algae were no longer found in this period (July) and consequently the less quantity of algae was recorded in the gut of Naziritor chelynoides. Comparatively the higher value of sand /silts and clay (20.18) was found during the month of July. The highest value of diatoms (24.67) was found in the month of January and lowest value (15.24) was found in the month of July. Similarly, plant fragments were reached in peak value (5.28) in the 
month of July and lowest value (2.37) in the month of January and during April no plant fragments was obtained. The highest value of detritus (21.14) was found in the month of April and lowest value (8.29) was found in the month of January. That mean variation of food items in gut also depends on seasons. The average annual percentage of gut contents of the fish is shown in Figure 01.

Fig. 01: Average Annual Percentage of Gut contents of Naziritor chelynoides

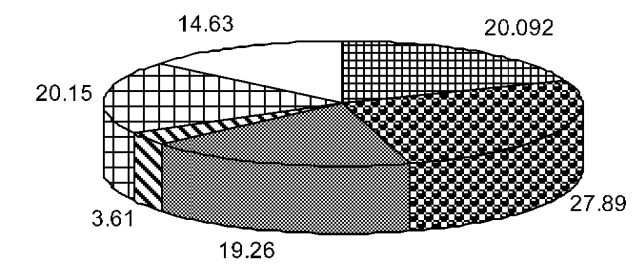

\begin{tabular}{|ll|}
\hline$\square$ Insects & Q Algae (green and blue green) \\
Diatoms & $\mathbf{D F r a g m e n t s}$ \\
$\boxminus$ Sand/Silt and Clay & $\square$ Detritus \\
\hline
\end{tabular}

Figure 01 shows the average annual percentage of gut contents which explains the annual percentage of algae (27.89), insects (20.15), diatoms (19.26), and fragments (3.61) respectively. Besides algae, the gut content was also found with different aquatic insects. According to Needham and Needham (1969) over $85 \%$ of the hill streams organisms contain 5 main groups of insects. They are caddis flies, mayflies, stoneflies, two- winged flies and alderflies. The present study recorded three groups namely caddis flies, mayflies and stoneflies.

Table 01: Average Percentage of insects in Gut of Naziritor chelynoides in different months (July 2003 to April 2004)

\begin{tabular}{|c|c|c|c|c|c|c|}
\hline \multirow[b]{2}{*}{ Dietary Items } & \multicolumn{4}{|c|}{ Months } & \multirow[b]{2}{*}{ Total } & \multirow[b]{2}{*}{ Average } \\
\hline & July & October & January & April & & \\
\hline \multicolumn{7}{|l|}{ Insects } \\
\hline Stonefly (Perlidae) & 6.34 & 8.37 & 9.00 & 4.59 & 28.3 & 7.07 \\
\hline Mayfly (Baetidae) & 1.25 & 2.56 & 2.83 & 1.83 & 8.47 & 2.18 \\
\hline Caddisfly (Leptoceridae) & 0.78 & - & 2.53 & 3.65 & 6.96 & 2.32 \\
\hline Cranefly (Simulidae) & 1.30 & 3.20 & - & - & 4.5 & 2.25 \\
\hline \multicolumn{7}{|l|}{ Aquatic beetles } \\
\hline Elmidae & 2.63 & 4.35 & - & 3.88 & 10.86 & 3.62 \\
\hline Corydalidae & 3.15 & 2.28 & 4.46 & 0.98 & 10.87 & 2.71 \\
\hline
\end{tabular}

During the study period the highest value of stonefly (9.00) was recorded in the month of January and lowest value (4.59) was recorded in the month of April. Similarly, highest value of mayfly (2.83) was recorded in the month of January and lowest value (1.25) was recorded in the month of July. The details of the gut contents of insects are shown in table 01. Caddisfly, 
cranefly and aquatic beetle (Elmidae) were absent in the month of October, January and April and January respectively. Among them stoneflies were most dominant during the study period and crane flies seemed to be least dominant. Though dietary variations take place in different months, the lives of omnivorous fishes are not too much affected because if plant foods are absent then they feed on animal foods and vice versa.

\section{Water Quality Analysis}

Dissolved oxygen also known as life supporting factor, plays an important role in aquatic lives. Lower oxygen concentration kills the fish and other organisms that are present in the water. Dissolved oxygen above $5 \mathrm{mg} / \mathrm{l}$ is suitable for the support of diverse biota (APHA, 1976). The average dissolved oxygen of Mardi Khola was found as optimum i.e. $11.06 \mathrm{mg} / \mathrm{l}$ ranging from $9.76 \mathrm{mg} / \mathrm{l}$ to $12.65 \mathrm{mg} / \mathrm{l}$., a good natural habitat suitable for diverse aquatic lives. Generally low $\mathrm{pH}$ value is harmful to fishes. Water having $\mathrm{pH}$ value below than 5.0 and above 9.5 are not suitable (APHA, 1976). This value was also optimum with an average 8.41. Transparency is also one of the important factors which directly or indirectly determine the productivity of water following the activities of aquatic organisms including fish. When turbidity is high, transparency is low which restricts the penetration of sunlight reducing photosynthetic activity. During the study period the water remained as transparent (crystal clear) except in rainy season. The transparency showed high negative correlation with fish catch, i.e. lower fish catch was recorded at higher transparency and vice versa. Temperature also plays an important role in floral and faunal diversity in aquatic environment. A variation in temperature has an important influence on all the aquatic organisms including fishes. Reproduction, growth and breathing rates of fish are directly dependent upon temperature variation. The oxygen content of water generally decreases with the rise in temperature. The temperature of Mardi Khola ranged from $10^{\circ} \mathrm{C}$ to $26^{\circ} \mathrm{C}$. The highest temperature of $26^{\circ} \mathrm{C}$ was recorded in the month of July at fourth site. The lowest temperature of $10^{\circ} \mathrm{C}$ was recorded in the month of January at first and second sites respectively. Figure 02, 03, 04, and 05 show the temperature and transparency versus fish catch number respectively in different months i.e., July, October, January and April.

Figure 02: Fish Catch Vs Water Temperature (III site) in four different months i.e. July, October, January and April

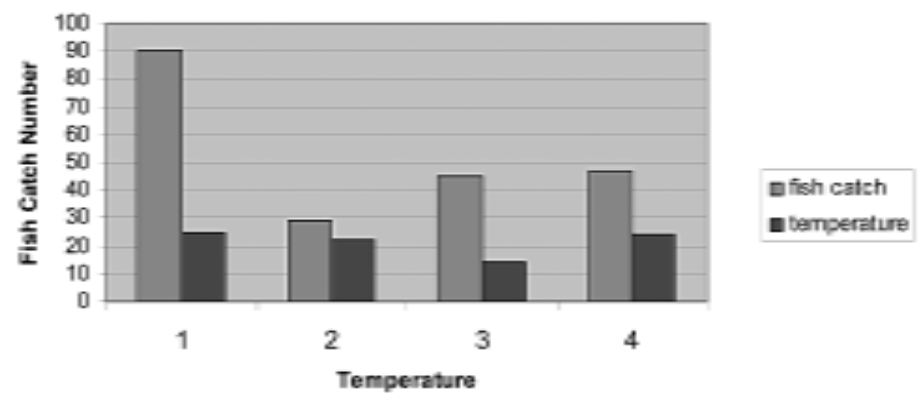


Figure 03: Fish Catch Vs Water Temperature (IV site) in four different months i.e. July, October, January and April

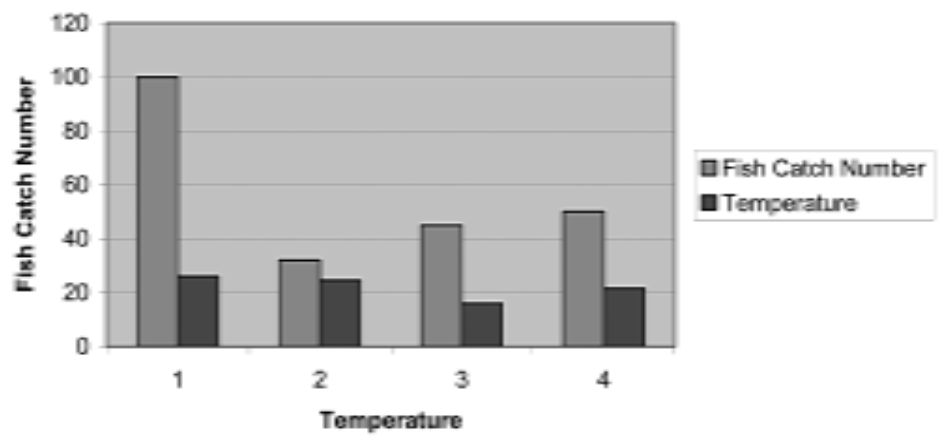

Figure 04: Fish Catch Vs Water Transparency (III site) in four different months i.e. July, October, January and April

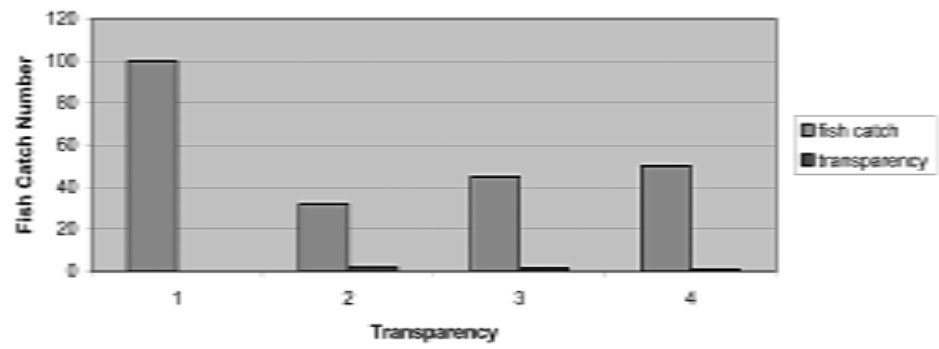

Figure 05: Fish Catch Vs Water Transparency (IV site) in four different months i.e. July, October, January and April

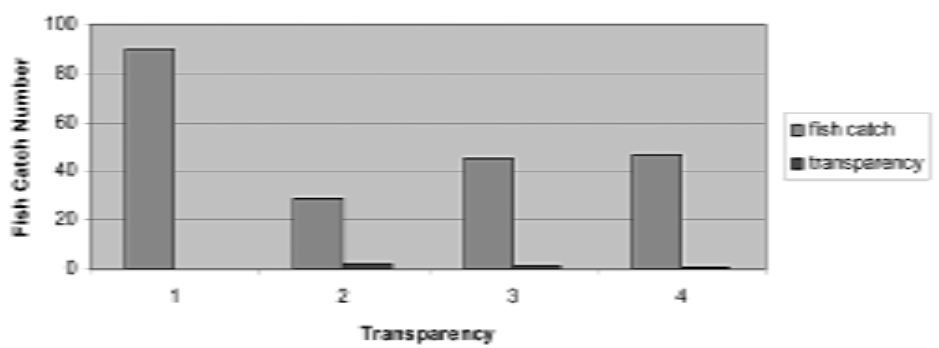




\section{Condition Factor}

Condition of fish is expressed by the ratio of length to weight of the fish at any given moment. The fish is said to have a better condition when this ratio is large. The average coefficient condition of Naziritor chelynoides was found as 1.31 indicating the state of well being with regards to the growth of fishes of the study area i.e. Mardi Khola. The highest and lowest values of condition factors were recorded in the months of July and April respectively.

Fig. 06: Average value of Coefficient of condition of Naziritor chelynoides

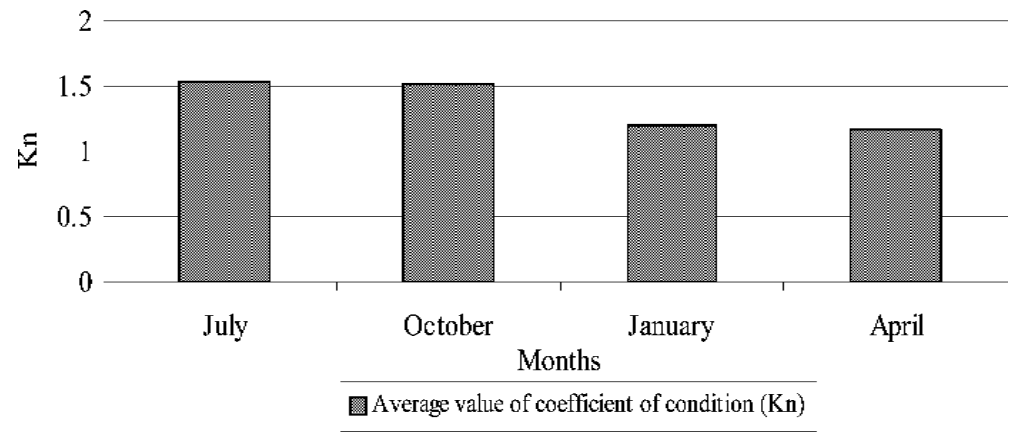

Food selectivity of Naziritor chelynoides was found as negative. That means the fish was non-selective i.e. avoidance of selection of dietary items in food intaking process, however, only few dietary items showed positive food selectivity indicating the food preference.

\section{Phytoplankton}

Four families of phytoplanktons were recorded from the river during the study period. These were Chlorophyceae, Cynophyceae, Bacillariophyceae and Desmiadiaceae. Two genera were reported from each family of chlorophyceae and desmiadiaceae while five genera were reported from each family of Cynophyceae and Bacillariophyceae respectively. During the study period phytoplanktons and zooplanktons were recorded only from III and IV sites. Table 02 explains the distribution and frequency of phytoplankton of Mardi Khola. The highest and lowest frequency occurrences were $16.60 \%$ of Synedra sp. and $0.82 \%$ of Scenedesmus sp. and Cosmarium sp. respectively. The total number of phytoplankton found at III and IV sites were 684,000 and 698,000 no/liter. Similar total numbers of phytoplanktons were reported by Bajracharya (2001), ranging from 90,200 to 1,276,000 no/liter from Bhotekoshi and Sunkoshi rivers respectively. Shrestha (1994) reported a total phytoplankton number abundance in Sunkoshi river at Dolalghat was 1,420,112 no/ liter. The phytoplankton abundance and fish catch showed positive correlation. That means higher the phytoplankton abundance greater the fish catch and vice versa. The zooplanktons were recorded very fewer in comparison to phytoplanktons that belong to the phyla Rotifera and Arthropoda respectively. 
Table 02: Distribution and Frequency of Phytoplankton at two sites in the Mardi Khola (July 2003 to April 2004)

\section{Conclusion}

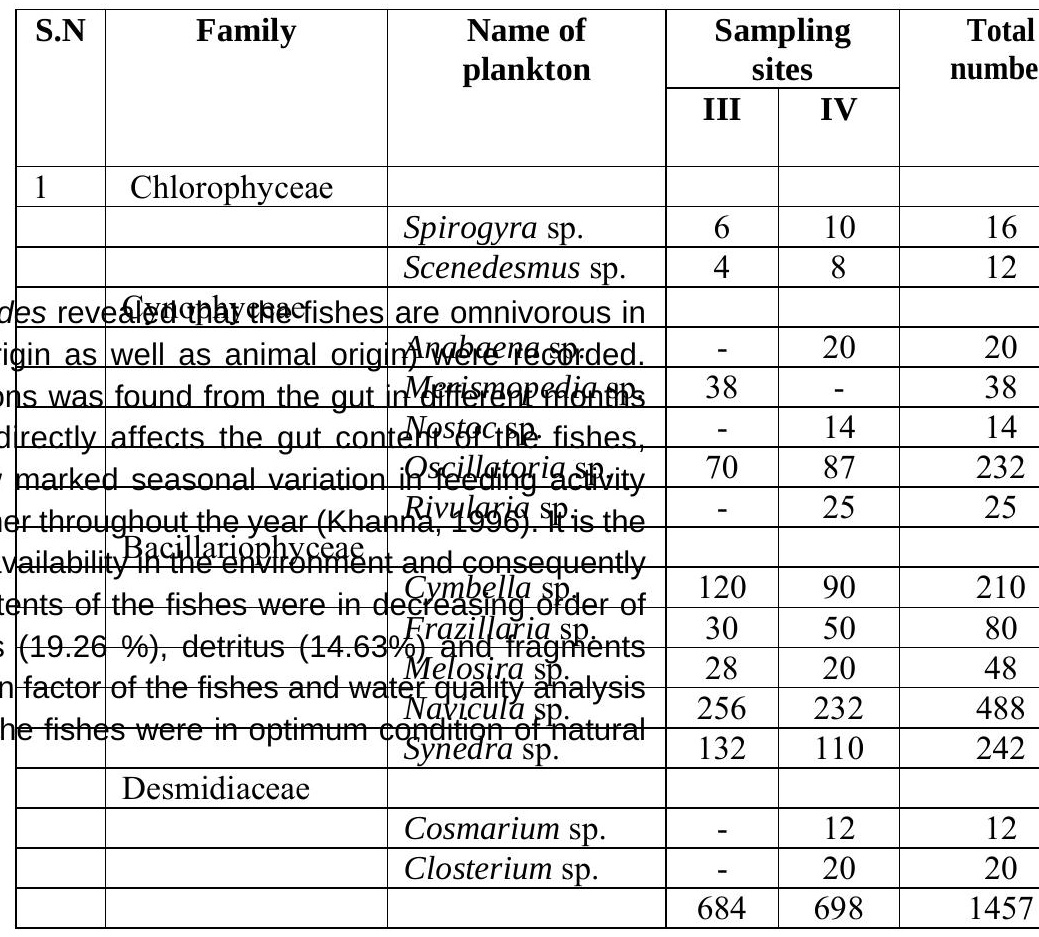




\section{Acknowledgements}

we would like to express our sincere thanks to Dr. Dharaniman Singh, Mr. Bikash Chanda Shrestha and Mr. Bishnu K. Silwal, Directorate of Fishery Development, Balaju for providing opportunity and lab facilities.

\section{References}

APHA, $(1976,95)$. Standard methods for the examination of water \& waste water. APHA, Washington DC.

Bajracharya, B. (2001). Fish and fishery rersources of the Bhotekoshi and Sunkoshi River. M.Sc. Dissertation in Zoology, T.U., Kirtipur (Unpublished)

Jayaram, K. C. (1981). The freshwater fishes of India, Pakistan, Bangladesh, Burma and Srilanka. Edited and Publication by the Dirc. of Zoological survey of India.

Jayaram, K. C. (1999). The freshwater fishes of Indian region, Narendra Publishing house, Delhi, India:551.

John, A. (1986). Morphological adaptation of fishes of river Seti and adjoining area. Ph.D. Dissertation, Patana University, India.

Karki, S.D. (1978). Studies on the feeding habits of Schizothoraicthys annandalei with relation to modification in digestive tract and brain. M. Sc. Dissertation in Zoology, T.U. Kathmandu (Unpublished).

Khanna, S. S. (1996). An introduction to fishes. Fourth edition, Central Book Depot, Allahabad.

Needham, J. G. and Needham, P. R. (1962). A guide to the fresh- water biology. Holiden- Day, INC., San Francisco.

$\mathrm{Ng}, \mathrm{H}$. H. (2006). The identity of Pseudechenis sulcatus (Mc Clelland) with description of two new species of Rheophitic cat fish (Teleostei: Sissoridae). Zootaxa, 1254:45-68.

$\mathrm{Ng}, \mathrm{H}$. H. and D. R. Edds. (2004). Batasio macronotus, a new species of Bagrid cat fish from Nepal (Teleostei: Bagridae). Ichthyol. Explor. Freshwaters, 15(4):295-307.

Ng, H. H. and D. R. Edds. (2005 a.) Two new species of Erethistoides (Teleostei: Erethistidae) from Nepal. Ichthyol. Explor. Freshwaters, 16(3):239-248.

Ng, H. H. and D. R. Edds. (2005 b). Two new species of Pseudecheneis rheophilic cat fish (Teleostei: Sissoridae) from Nepal. Zootaxa, 1047:1-19.

Pennak, R.W. (1978). Fresh water invertebrates of the United States. John Wiley and Sons Inc. New York:803.

Rai, A. K. (1989). Final progess report (16 July 1984- Dec. 1988). Inland Fisheries

Project, Indrasarobar, Kulekhani, Nepa:73.

Rajbanshi, K.G. (2005). Review on current taxonomic status and diversity of fishes of Nepal. Royal Nepal Academy of Science and Technology. Occasional paper No.10:41.

Shrestha, B.C. (1974). The functional anatomy of the Alimentary canal of Pseudoechenis 
sulcatus (Mc Clelland) and its feeding habits. M. Sc. Dissertation in Zoology, T.U. Kathmandu (Unpublished).

Shrestha, J. (1981). Fishes of Nepal. C. D. C. Tribhuvan University, Kathmandu, Nepal.

Shrestha, J. (1994). Fishes, Fishing Implements and Methods of Nepal. Smt. M. D. Gupta. Lalitpur colony, Lashkar (Gwalior), India. 150p.

Shrestha, J. (2003). Taxonomic revision of fishes of Nepal. Cold water fisheries in transHimalayan countries. FAO Fisheries Technical Paper No.s431:273-288

Shrestha, M. (1994). Distribution of Phytoplankton in relation to the physico-chemical Parameter of Sunkoshi river. M.Sc. Dissertation in Zoology, T.U., Kirtipur (Unpublished).

Shrestha, R. (1989). Study on food and feeding habits of some fish Channa gachua, Heteropneustes fossilis and Garra anandalei in relation to brain. M. Sc. Dissertation in Zoology, T.U. Kathmandu (Unpublished).

Shrestha, R. (1989). Study on food and feeding habits of some fish Channa gachua, Heteropneustes fossilis and Garra anandalei in relation to brain (unpublished).

Shrestha, S. K. (1993). Seasonal food and feeding habits of Schizothorax plagiostomus (Heckel) in the Phalangu River, Betrawati, Nuwakot. M. Sc. Dissertation in Zoology, T.U. Kathmandu (Unpublished).

Upadhya, K. (1976): Food and feeding habits and Alimentary canal of Schizothorax plagiostomus (Heckel).

\section{Author's Address}

Om Hari Shrestha and Jiwan Shreshta

omhs_2@hotmail.com

Central Department of Zoology, Tribhuvan University

Kirtipur, Kathmandu, Nepal 